\title{
PENYELIDIKAN EPIDEMIOLOGI KASUS COVID-19 PADA KLASTER PERKANTORAN DI KABUPATEN MUSI BANYUASIN
}

\author{
Ena Juhaina ${ }^{1}$ \\ ${ }^{1}$ BTKLPP Kelas I Palembang Kemenkes RI \\ Email : juhainaena@yahoo.com
}

\begin{abstract}
ABSTRAK
Covid-19 adalah penyakit jenis baru yang belum pernah diidentifikasi sebelumnya pada manusia yang merupakan penyakit menular pada saluran pernapasan yang disebabkan oleh novel Coronavirus yang ditegakkan melalui pemeriksaan PCR positif (Konfirmasi positif). Coronavirus adalah keluarga besar virus yang menyebabkan penyakit mulai dari gejala ringan sampai berat. Virus penyebab COVID-19 ini dinamakan Sars-CoV-2. Penelitian menyebutkan bahwa SARS ditransmisikan dari kucing luwak (civet cats) ke manusia dan MERS dari unta ke manusia. Adapun, hewan yang menjadi sumber penularan COVID-19 ini masih belum diketahui. Tujuan penyelidikan ini adalah untuk Memberikan dukungan teknis pelaksanaan surveilans dalam upaya pencegahan dan pengendalian peningkatan kasus Covid 19 di Kabupaten Musi Banyuasin. Kajian ini menggunakan rancangan studi cross-sectional dilaksanakan pada bulan September 2020. Populasi studi adalah Pegawai Kantor Pemerintahan di Kabupaten Musi Banyuasin. Sampel adalah Pegawai pada kantor sekretariat daerah dan Bappeda kabupaten Musi Banyuasin sebanyak 156 orang. Dilakukan Wawancara dengan menggunakan kuesioner serta pengambilan spesimen melalui swab hidung dan tenggorok untuk dilakukan pemeriksaan PCR bagi sampel yang terindikasi Covid-19 berdasarkan hasil Penyelidikan Epidemiologi. Berdasarkan hasil pemeriksaan PCR dari 8 spesimen yang dilakukan pemeriksaan PCR ditemukan 7 orang positif konfirmasi Covid-19. Petugas Puskesmas dapat melakukan surveilans ketat untuk menemukan dan mencegah adanya penambahan kasus.
\end{abstract}

Kata kunci : Covid-19; Virus Corona

\section{PENDAHULUAN}

Menurut para ahli hingga saat ini ada dua jenis coronavirus yang diketahui menyebabkan penyakit yang dapat menimbulkan gejala berat seperti Middle East Respiratory Syndrome (MERS) dan Severe Acute RespiratorySyndrome (SARS). Coronavirus adalah keluarga besar virus yang menyebabkan penyakit mulai dari gejala ringan sampai berat. Ada setidaknya dua jenis coronavirus yang diketahui menyebabkan penyakit yang dapat menimbulkan gejala berat seperti Middle East Respiratory Syndrome (MERS) dan Severe
Acute Respiratory Syndrome (SARS). Coronavirus Disease 2019 (COVID-19) adalah penyakit jenis baru yang belum pernah diidentifikasi sebelumnya pada manusia. Covid-19 adalah penyakit menular pada saluran pernapasan yang disebabkan oleh novel Coronavirus yang ditegakkan melalui pemeriksaan PCR positif (Konfirmasi positif). Virus penyebab COVID-19 ini dinamakan Sars-CoV-2. Virus corona adalah zoonosis (ditularkan antara hewan dan manusia). Penelitian menyebutkan bahwa SARS ditransmisikan dari kucing luwak (civet cats) ke manusia dan MERS dari unta ke 
manusia. Adapun, hewan yang menjadi sumber penularan COVID-19 ini masih belum diketahui.

Tanda dan gejala umum infeksi COVID-19 antara lain gejala gangguan pernapasan akut seperti demam, batuk dan sesak napas.. Pada kasus COVID-19 yang berat dapat menyebabkan pneumonia, sindrom pernapasan akut, gagal ginjal, dan bahkan kematian. Tanda-tanda dan gejala klinis yang dilaporkan pada sebagian besar kasus adalah demam, dengan beberapa kasus mengalami kesulitan bernapas, dan hasil rontgen menunjukkan infiltrat pneumonia luas di kedua paru.

Masa inkubasi rata-rata 5-6 hari dengan masa inkubasi terpanjang 14 hari. Berdasarkan bukti ilmiah, COVID-19 dapat menular dari manusia ke manusia melalui percikan batuk/bersin (droplet), tidak melalui udara. Orang yang paling berisiko tertular penyakit ini adalah orang yang kontak erat dengan pasien COVID-19 termasuk yang merawat pasien COVID-19. Penularan terbatas antar manusia (seperti petugas kesehatan, keluarga yang merawat pasien).

Sampai dengan tanggal 25 Maret 2020, dilaporkan total kasus konfirmasi Covid-19 di Dunia ada sebanyak 414.179 kasus dengan kematian sebanyak 18.440 (CFR 4,4\%) menurut kasus yang dilaporkan di 192 negara/wilayah. Di antara kasus tersebut sudah ada beberapa petugas kesehatan yang dilaporkan terinfeksi.

Pada tanggal 2 Maret 2020, Indonesia melaporkan kasus konfirmasi Covid-19 sebanyak 2 kasus. sampai dengan tanggal 25 Maret 2020 , Indonesia melaporkan 790 kasus konfirmasi Covid-19 yang tersebar di 24 Provinsi.

Di Sumatera Selatan kasus covid-19 dilaporkan pertama kali pada tanggal 24 Maret 2020, sampai dengan tanggal 15 September 2020 dilaporkan sebanyak 5118 kasus konfirmasi Covid-19 dan 309 kasus diantaranya meninggal.

Di Kabupaten Musi Banyuasin dilaporkan hingga tanggal 15 September 2020 sebanyak 116 kasus konfirmasi Covid19. Di antara kasus konfirmasi positif tersebut ditemukan berasal dari klaster perkantoran. Berdasarkan informasi tersebut BTKLPP Kelas I Palembang berkoordinasi dengan Dinas Kesehatan Kabupaten Musi Banyuasin membentuk tim penyelidikan Epidemiologi untuk melakukan serangkaian kegiatan penyelidikan dan penanggulangan kasus Covid-19 di Kabupaten Musi Banyuasin.

Selanjutnya Tim BTKLPP Kelas I Palembang melakukan screening pada kelompok yang berisiko terpapar virus Covid19, dalam hal ini adalah kelompok pekerja perkantoran yang bertugas di Sekretariat Daerah Kabupaten Musi Banyuasin dan Bappeda (Badan Perencanaan Pembangunan Daerah) Kabupaten Musi Banyuasin. Dikarenakan ditemukan satu kasus konfirmasi positif yang bekerja di Bappeda Musi Banyuasin, sehingga perlu dilakukan screening rapid tes antibodi IgG dan IgM Covid-19 dan Swab Antigen (Ag) pada pegawai di Bappeda dan Sekda Kabupaten Musi Banyuasin.

Tujuan penyelidikan ini adalah untuk Memberikan dukungan teknis pelaksanaan surveilans dalam upaya pencegahan dan 
pengendalian peningkatan kasus Covid $19 \mathrm{di}$

Kabupaten Musi Banyuasin.

\section{METODE}

Kajian ini menggunakan rancangan studi cross-sectional dilaksanakan pada bulan September 2020. Populasi studi adalah Pegawai Kantor Pemerintahan di kabupaten Musi Banyuasin. Sampel adalah Pegawai pada kantor sekretariat daerah dan Bappeda kabupaten Musi Banyuasin sebanyak 156 orang. Wawancara dengan menggunakan kuesioner serta pengambilan spesimen melalui swab hidung dan tenggorok untuk dilakukan pemeriksaan PCR bagi sampel yang terindikasi Covid-19 berdasarkan hasil Penyelidikan Epidemiologi.

\section{Gambaran Hasil Survey}

Dalam kegiatan penyelidikan epidemiologi ini dilakukan survey terhadap 156 responden yang merupakan pegawai di kantor Bappeda dan sekretariat Daerah Kabupaten Musi Banyuasin. Sumber informasi didapatkan melalui wawancara dengan responden yang kooperatif dengan menggunakan form screening.

- Laki-laki

- Perempuan

\section{Gambar 1. Persentase Responden Berdasarkan Jenis Kelamin}

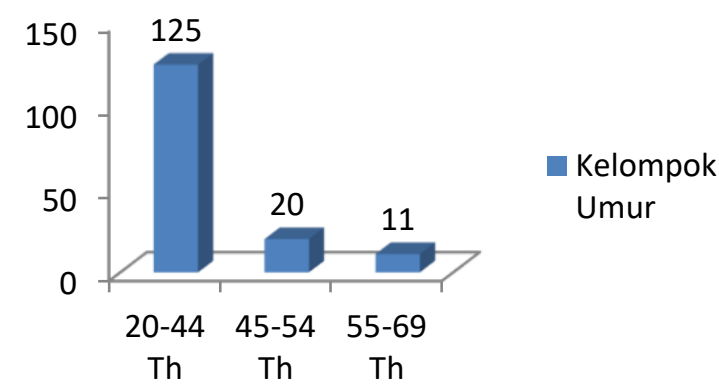

Gambar 2. Distribusi Responden Berdasarkan Kelompok Umur

Berdasarkan jenis kelamin jumlah lakilaki dan peremouan sama banyak (78 orang). Gambar 2 melukiskan bahwa distribusi responden berdasarkan kelompok umur didominasi pada kelompok umur 20-44 tahun sebanyak 125 orang $(80,1 \%)$. 




\section{Gambar 3 Distribusi Responden Berdasarkan Gejala}

Responden pada umumnya tanpa gejala tenggorok. Diantara responden yang tanpa (OTG) sebanyak $91,7 \%$ (143 orang) gejala terdapat 5 orang yang memiliki penyakit sedangkan yang dengan gejala sebanyak penyerta (komorbid) yaitu Diabetes Mellitus, $8,3 \%$ ( 13 orang). Gejala yang dirasakan hanya Hipertensi dan Asma.

sebatas demam biasa, pilek dan sakit

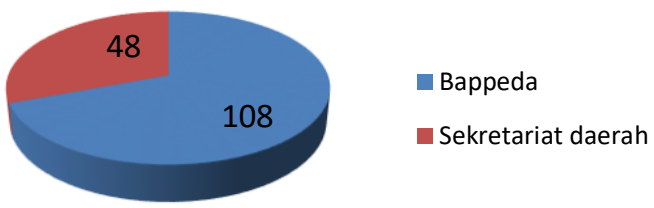

\section{Gambar 4 Distribusi Responden Berdasarkan Tempat}

Gambar 4 mengilustrasikan bahwa sebagian besar responden berasal dari Kantor Bappeda sebesar $69,2 \%$ (108 orang). Hal ini dikarenakan kontak kasus adalah teman sejawat dengan kasus dan sekantor.

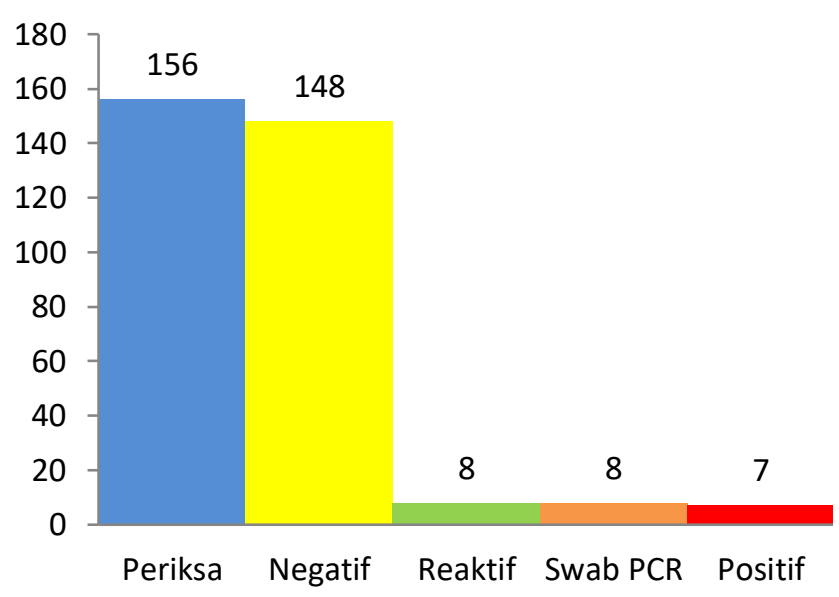

Gambar 5 Hasil screening Responden 
Dari 156 orang yang discreening ada 100 orang yang dirapid swab Antigen hasilnya 2 orang positif sedangkan yang dilakukan rapid tes IgG/IgM ada 68 orang, karena ada 12 orang kontak erat kasus di Bappeda yang telah melakukan rapid tes IgG/lgM juga melakukan tes swab Antigen untuk pemastian hasil screening atas 'permintaan Kepala Bappeda. Hasil pemeriksaan $\lg \mathrm{G} / \mathrm{lgM}$ menunjukkan terdapat 6 orang reaktif. Total 8 orang yang positif dan reaktif berdasarkan hasil screening ini terdiri 3 orang pegawai Sekda (Tata Pemerintahan) dan 5 orang pegawai Bappeda. Selanjutnya dilakukan swab nasofaring terhadap sampel yang reaktif dan swab orofaring pada sampel yang positif berdasarkan rapid tes swab $\mathrm{Ag}$ sehingga pada tahapan berikutnya spesimen akan dilakukan pemeriksaan PCR di Laboratorium PCR BTKLPP Kelas I Palembang.

Dari 8 spesimen yang dilakukan pemeriksaan PCR ditemukan 7 orang positif konfirmasi Covid-19. Kasus merupakan pegawai di Bappeda dan Sekda Kabupaten Musi Banyuasin tidak disertai gejala (asimptomatik). Terhadap kasus yang konfirmasi positif ini segera diberikan treatment dengan melakukan isolasi mandiri dengan pemantauan dari Puskesmas setempat terhadap kondisi kesehatannya selama 14 hari sampai hasil pemeriksaan PCRnya negatif. Petugas Puskesmas juga melakukan tracing terhadap kontak erat kasus baru konfirmasi positif Covid-19

\section{DISKUSI DAN ANALISIS}

1. Salah satu faktor risiko terjadinya penularan Covid 19 adalah adanya riwayat kasus terkonfirmasi positif melakukan perjalanan ke daerah wabah atau ada tamu yang datang dari lokasi wabah. Kemungkinan ada kontak erat dengan orang yang bepergian ke daerah wabah sehingga dapat dikatakan kasus terpapar oleh orang tersebut yang OTG. Artinya kemungkinan penularan adalah adanya penderita carier namun tidak menunjukkan gejala Covid-19 (OTG) di wilayah terjangkit.

2. Lambatnya deteksi dini dan penanganan kasus konfirmasi positif Covid-19 menjadi salah satu faktor risiko penyebaran kasus secara masif. Ini terbukti dari beberapa kasus konfirmasi terlambat ditangani sehingga kontak erat kasus sulit dilacak. Keterlamabatan deteksi dini dan penanganan kasus Covid-19 ini juga disebabkan lamanya hasil laboratorium pemerikasaan PCR sehingga kontak kasus yang diambil spesimennya tidak sabar menunggu hasilnya. Hal ini menyebabkan para kontak kasus tidak optimal melakukan isolasi dan orang-orang yang pernah kontak dengan sampel sulit dilacak kembali keberadaannya sehingga kasus sudah berkeliaran kemana-kemana.

3. Penyediaan tempat yang layak dan representatif untuk isolasi bagi pasien/kasus konfirmasi positif Covid-19 serta penatalaksanaan kasus menjadi faktor penyebab mempercepat masa penyembuhan kasus.

4. Kurangnya pengetahuan tentang pencegahan penularan Covid 19. Hal ini dibuktikan ketika kasus melakukan perjalanan belum menerapkan protokol kesehatan Covid 19, sehingga kasus dimungkinkan terpapar dari daerah wabah.

5. Kebijakan penerapan protokol kesehatan terkait Covid 19 di Kabupaten Musi Banyausin belum dilaksanakan secara 
maksimal oleh masyarakat baik di perkantoran maupun di tempat-tempat umum, hal ini nampak masih ada sebagian masyarakat masih belum menerapkan protokol kesehatan terkait Covid 19.

6. diterapkan. Hal ini dimungkinkan masyarakat belum mengetahui dan memahami betul tentang mekanisme penularan penyakit Covid 19 serta bahayanya bagi yang kelompok yang berisiko.

7. Belum adanya penegakan sanksi tegas terhadap pelanggar protokol kesehatan

\section{UPAYA YANG TELAH DILAKUKAN}

Dalam rangka pengendalian dan penanganan kasus Covid-19 di Kabupaten Musi Banyuasin telah dilakukan secara terintegrasi yaitu melibatkan lintas program Dinas Kesehatan (dokter, perawat, epidemiolog sanitarian dan promkes) maupun lintas sektor yang melibatkan beberapa instansi terkait yang tergabung dalam satuan tugas penanganan Covid-19. Upaya yang telah dilakukan oleh Satuan Tugas Covid-19 Kabupaten Musi Banyuasin, antara lain adalah sebagai berikut :

1. Penerapan Protokol Kesehatan di Dinas Kesehatan Kabupaten Musi Banyuasin dan di tingkat Puskesmas terkait pelayanan kepada masyarakat yaitu : adanya tempat cuci tangan dengan sabun dan air mengalir, tersedia tissue dan tempat sampah, pengukuran suhu, kewajiban menggunakan masker, menggunakan sarung tangan bagi petugas sebelum dan sesudah menjalankan tugas maupun pasien serta tamu yang datang ke tempat tersebut.
Masyarakat masih menganggap hal biasa masalah covid 19 apalagi banyak kasus yang tidak menunjukkan gejala sehingga istilah new normal juga belum

2. Pekerja puskesmas yg bertugas di bagian penerimaan pasien sudah menggunakan APD level 2, sedangkan pekerja yang bagian swab menggunakan APD level 3. Untuk ruang pelayanan khusus pasien covid disiapkan satu area yang terpisah dengan pasien lainnya.

3. Sosialisasi dan edukasi kepada masyarakat tentang penerapan protokol kesehatan Covid-19. Terdapat banner pencegahan covid19 sehingga masyarakat dapat langsung melihat bagaimana cara pencegahan covid19 di ruang tunggu Puskesmas.

4. Pelaksanaan On The Job training (OJT) bagi Analis Kesehatan Puskesmas terkait pengambilan swab nasofaring dan orofaring kontak kasus Covid-19

5. Melakukan koordinasi lintas sektor terkait adanya temuan kasus baru yang berasal dari luar wilayah Kabupaten Musi Banyuasin

6. Setiap ada temuan kasus baru konfirmasi positif Covid-19, Tim PE Puskesmas bersama tim satuan tugas Covid-19 melakukan tracing, testing dan treatment terhadap kontak erat kasus konfirmais positif Covid-19

7. Dilakukan Pemeriksaan laboratorium PCR bagi kontak erat baik yang bergejala maupun tidak bergejala, sebagian besar sampel spesimen diperiksa di Laboratorium Rumah Sakit Sekayu dan bila melebihi kapasitas sampel spesimen 
dikirim ke BBLK Palembang dan Laboratorium BTKLPP Kelas I Palembang

8. Untuk kasus yang ringan sampai sedang dan tidak memerlukan perawatan medis disediakan tempat untuk isolasi mandiri di rumah Sehat Sekayu

9. Untuk pembuangan limbah di Puskesmas Lumpatan disediakan tempat limbah organik dan anorganik tetapi warna kotak sampah sama sebaiknya dibedakan warna limbah organik dan anorganik. Limbah cair yang berasal dari ruang kerja dialirkan ke IPAL sedangkan limbah cair dari kamar mandi di alirkan ke got. Limbah B3 dikumpulkan dalam satu tempat dan dimusnahkan dengan bekerjasama dengan RSUD Sekayu.

10. Desinfektan rutin dilakukan baik di dalam gedung maupun di luar gedung. Untuk DPA desinfektan melekat dalam anggaran APBD covid-19, rutin tiap 2 Minggu sekali di TTU (sekolah, tempat ibdah, pasar , terminal dll) dengan melibatkan pemberdayaan masyarakat setempat.

\section{KESIMPULAN}

1. Telah terjadi KLB Covid 19 di Kabupaten Musi Banyuasin

2. Setelah dilakukan tracing kasus ditemukan adanya penularan di lokasi KLB terjadi.

3. Sumber penularan berasal dari kontak kasus yang berpergian ke daerah wabah dengan status OTG, selanjutnya terjadi penularan lokal.

4. Masih kurangnya penerapan protokol kesehatan terkait Covid 19, misalnya : penggunaan APD (Masker), mencuci tangan serta physical distancing.
5. Komunikasi risiko di tingkat masyarakat belum berjalan dengan baik, sehingga pemahaman masyarakat tentang penyakit Covid 19 masih kurang, hal ini terlihat belum terlaksananya secara optimal protokol kesehatan covid 19.

6. Belum adanya penegakan sanksi hukum bagi pelanggar penerapan protokol kesehatan.

\section{REKOMENDASI}

1. Dinas Kesehatan Kabupaten Musi Banyuasin diharapkan dapat bekerja sama dengan BTKLPP Kelas I Palembang untuk melakukan Surveilans Epidemiologi bila ada peningkatan kasus.

2. Petugas Puskesmas diharapkan dapat memantau karantina mandiri terhadap orang kontak erat sampai ada hasil laboratorium atau selama 14 hari (2x masa inkubasi terpanjang).

3. Meningkatkan upaya peran serta aktif masyarakat di posko-posko Covid-19 yang telah dibentuk di masing-masing Desa untuk pencegahan dan pengendalian kasus Covid 19 di wilayah Puskesmas Lumpatan khususnya dan wilayah Kabupaten Musi Banyuasin pada umumnya

4. Tim satgas Covid 19 Puskesmas diharapkan meningkatkan komunikasi risiko kepada masyarakat terkait upaya pencegahan dan pengendalian Covid 19.

5. Pemerintah daerah diharapkan segera menerapkan kebijakan sistem WFH (Work From Home) bagi pegawai Pemerintah di perkantoran atau perusahaan swasta mengingat ada temuan kasus pada klaster perkantoran 
serta memberikan sanksi tegas kepada kantor dan perusahaan yang melanggar khususnya penerapan protokol kesehatan yang meliputi 3M (memakai masker, mencuci tangan dan menjaga jarak) sesuai intruksi Presiden mengenai kampanye nasional pencegahan Covid 19.

\section{REFERENS|}

1. BNPB RI. 2020, Situasi COVID 19 di Indonesia 15 September 2020. Satuan Tugas Penanganan covid 19. Dari : Covid19.bnpb.go.id.

2. Dinas Kesehatan Provinsi Sumatera Selatan. 2020, Update Situasi Coronavirus Sumsel 15 September 2020. Dinas Kesehatan Provinsi Sumatera Selatan, Sumatera Selatan. Dari: https://dinkes.sumselprov.go.id/update-situasi-coronavirus-sumsel-15-September-2020/.

3. Forum Academia NTT. 2020, Panduan menghadapi penyakit virus corona 2019 Model RRC, pencegahan, pengendalian, diagnosis dan manajemen. NTT : Forum Academia.

4. Kemenkes RI. 2020, Pedoman Pencegahan dan Pengendalian Coronavirus Disease (Covid 19). Jakarta: Direktorat Jenderal Pencegahan dan Pengendalian Penyakit. 